\title{
Mating system parameters in a high density population of andirobas in the Amazon forest
}

\author{
Tatiana de Campos $^{(1)}$, Marcia Oliveira da Cunha ${ }^{(2)}$, Adna Cristina Barbosa de Sousa( ${ }^{(3)}$, Renata Beltrão Teixeira(1), \\ Andrea Raposo ${ }^{(1)}$, Alexandre Magno Sebbenn ${ }^{(4)}$ and Lucia Helena de Oliveira Wadt ${ }^{(1)}$

\begin{abstract}
(1)Embrapa Acre, Rodovia BR 364, Km 14, Caixa Postal 321, CEP 69908-056 Rio Branco, AC, Brazil. E-mail: tatiana.campos@embrapa.br, renata.beltrao@embrapa.br, andrea.raposo@embrapa.br, lucia.wadt@embrapa.br (2)União Educacional do Norte, BR 364, Km 02, Alameda Hungria, no 200, Jardim Europa II, CEP 69915-497 Rio Branco, AC, Brazil. E-mail: marciameubem@live.com (3)Universidade do Estado da Bahia, Departamento de Biologia Vegetal, Campus VIII, Rua do Bom Conselho, no 179, CEP 48608-240 Paulo Afonso, BA, Brazil. E-mail: adnacsousa@gmail.com ${ }^{(4)}$ Instituto Florestal de São Paulo, Estação Experimental de Tupi, Rodovia Luiz de Queiroz, Km 149, Caixa
\end{abstract} \\ Postal 339, CEP 13400-970 Piracicaba, SP, Brazil. E-mail: alexandresebbenn@yahoo.com.br
}

\begin{abstract}
The objective of this work was to estimate the mating system parameters of a andiroba (Carapa guianensis) population using microsatellite markers and the mixed and correlated mating models. Twelve open-pollinated progeny arrays of 15 individuals were sampled in an area with C. guianensis estimated density of 25.7 trees per hectare. Overall, the species has a mixed reproductive system, with a predominance of outcrossing. The multilocus outcrossing rate $\left(\mathrm{t}_{\mathrm{m}}=0.862\right)$ was significantly lower than the unity, indicating that self-pollination occurred. The rate of biparental inbreeding was substantial $\left(t_{m}-t_{s}=0.134\right)$ and significantly different from zero. The correlation of selfing within progenies was high $\left(r_{s}=0.635\right)$, indicating variation in the individual outcrossing rate. Consistent with this result, the estimate of the individual outcrossing rate ranged from 0.598 to 0.978 . The multilocus correlation of paternity was low $\left(\mathrm{r}_{\mathrm{p}(\mathrm{m})}=0.081\right)$, but significantly different from zero, suggesting that the progenies contain full-sibs. The coancestry within progenies $(\Theta=0.185)$ was higher and the variance effective size $\left(\mathrm{N}_{\mathrm{e}(\mathrm{v})}=2.7\right)$ was lower than expected for true half-sib progenies $\left(\Theta=0.125 ; \mathrm{N}_{\mathrm{e}(\mathrm{v})}=4\right)$. These results suggest that, in order to maintain a minimum effective size of 150 individuals for breeding, genetic conservation, and environmental reforestation programs, seeds from at least 56 trees must be collected.
\end{abstract}

Index terms: Carapa guianensis, allogamy, conservation, genetic breeding, microsatellite, population size.

\section{Parâmetros do sistema reprodutivo em uma população de alta densidade de andirobas na Floresta Amazônica}

Resumo - O objetivo deste trabalho foi estimar parâmetros do sistema reprodutivo de uma população de andirobas (Carapa guianensis), com uso de marcadores microssatélites e de modelos de cruzamentos mistos e correlacionados. Doze arranjos de progênies com 15 indivíduos oriundos de polinização aberta foram amostrados em área com densidade populacional de andirobas de 25,7 árvores por hectare. No geral, a espécie tem um sistema misto de reprodução, com predominância de fecundação cruzada. A taxa de reprodução multiloco $\left(\mathrm{t}_{\mathrm{m}}=0,862\right)$ foi significativamente menor que a unidade, o que indica que houve autofecundação. A taxa de cruzamento entre indivíduos aparentados foi substancial $\left(t_{m}-t_{s}=0,134\right)$ e significativamente diferente de zero. A correlação de autofecundação nas progênies foi alta $\left(r_{s}=0,635\right)$, o que indica taxa de fecundação cruzada individual variável. Em consonância com esse resultado, a estimativa da taxa de fecundação cruzada individual variou de 0,598 a 0,978 . A correlação multiloco de paternidade foi baixa $\left(\mathrm{r}_{\mathrm{p}(\mathrm{m})}=0,081\right)$, mas significativamente diferente de zero, o que sugere progênies com irmãos completos. A coancestria dentro das progênies $(\Theta=0,185)$ foi maior e o tamanho efetivo de variância $\left(\mathrm{N}_{\mathrm{e}(\mathrm{v})}=2,7\right)$ foi menor que o esperado para verdadeiras progênies de meios-irmãos $\left(\Theta=0,125 ; \mathrm{N}_{\mathrm{e}(\mathrm{v})}=4\right)$. Esses resultados sugerem que, para manter um tamanho efetivo mínimo de 150 indivíduos, para melhoramento, conservação genética e programas de reflorestamento ambiental, sementes de pelo menos 56 árvores devem ser coletadas.

Termos para indexação: Carapa guianensis, alogamia, conservação, melhoramento genético, microssatélite, tamanho de população.

\section{Introduction}

Andiroba (Carapa guianensis Aubl.) is a deciduous tree from the Meliaceae family commonly found in the
Neotropics (Dayanandan et al., 1999; Cloutier et al., 2007b). The species inhabits the upland and floodplain forests of the Amazon basin (Cloutier et al., 2007b). It

Pesq. agropec. bras., Brasília, v.48, n.5, p.504-509, maio 2013

DOI: 10.1590/S0100-204X2013000500006 
is economically important as a source of timber and oil (Cloutier et al., 2007a, 2007b). The seeds consist of a large kernel containing a high proportion of lipids, and the oil is widely used for medicines, cosmetics, and insect repellency (Revilla, 2001). In the Brazilian Amazon forest, individuals can reach up to $65 \mathrm{~cm}$ of stem diameter at breast height (DBH) (Martins et al., 2012). The population density of reproductive individuals is relatively high in natural forest ( $>5$ trees per hectare), but variable among populations (Dayanandan et al., 1999; Cloutier et al., 2007a; Martins et al., 2012).

Despite the economic potential of andiroba, there is still little information about its botanics, ecological, and genetics. In general, due to the intensive logging of the species in the Amazon forest, genetic studies have been focusing on the effects of this practice on mating systems and gene flow (Hall et al., 1994; Cloutier et al., 2007b; Klimas et al., 2007; Raposo et al., 2007; Martins et al., 2012). However, no studies have been carried out to investigate coancestry levels, effective size, and sample size for purposes of genetic breeding, conservation, and environmental reforestation plans. Reproductive biology, mating systems, pollen and seed dispersal (gene flow), and intra-population spatial genetic structure (SGS) have a strong effect on the genetic composition of natural populations. The mating system patterns of a species determine the levels of relatedness and inbreeding within open-pollinated progenies, and such information is essential to estimate sample size for genetic breeding and conservation, as well as for collecting seeds to be used in environmental reforestation plans (Sebbenn, 2006).

Carapa guianensis is an insect pollinated monoecious tree, predominantly outcrossed (Hall et al., 1994; Cloutier et al., 2007b). Hall et al. (1994) found outcrossing rates that were not significant and different from 1.0 in unlogged $\left(\mathrm{t}_{\mathrm{m}}=0.967\right)$ and in logged $\left(\mathrm{t}_{\mathrm{m}}=0.989\right)$ populations, in Costa Rica. However, Cloutier et al. (2007b) observed outcrossing rates significantly different from 1.0 (0.939 before logging and 0.927 after logging), in a population from the Brazilian Amazon forest (state of Pará), which suggests the occurrence of some selfing. Furthermore, both pollen and seeds can be long-distance dispersed ( $>430 \mathrm{~m}$ for pollen and $>397 \mathrm{~m}$ for seeds) (Martins et al., 2012), and this may explain the observed weak SGS in natural and logged populations (Cloutier et al., 2007b; Martins et al., 2012), and the absence of biparental inbreeding found in logged and unlogged populations (Cloutier et al., 2007b). However, mating system patterns may vary among populations, individuals within a population, flowers within individuals, and within different reproductive events (Sebbenn, 2006; Feres et al., 2012), since they are affected by both biotic and abiotic factors (Sebbenn, 2006). Therefore, it is necessary to study the mating system of a species in more than one population, with several individuals and reproductive events (Sebbenn, 2006; Feres et al., 2012). For genetic breeding, conservation, and reforestation purposes, it is also important to know inbreeding levels, coancestry coefficient, and effective size within open-pollinated progenies because these genetic parameters allow to estimate the required sample size in order to retain a specific effective population size (Sebbenn, 2006; Feres et al., 2012).

The objective of this work was to estimate the mating system parameters of a andiroba (C. guianensis) population, using microsatellite markers and the mixed and correlated mating models.

\section{Materials and Methods}

The study was carried out in the 1,200 ha experimental forest of the Brazilian Agricultural Research Corporation (Embrapa), in the southwestern portion of the state of Acre, Brazil $\left(10^{\circ} 01^{\prime} 28^{\prime \prime} \mathrm{S}\right.$, $\left.67^{\circ} 42^{\prime} 19^{\prime \prime} \mathrm{W}\right)$. The experimental region has a lightly undulating topography, with a dominant vegetation classified as humid. The region has a pronounced three-month dry season, from June to August, and the annual mean temperature is $24.5^{\circ} \mathrm{C}$. The evaluated forest is an occasionally inundated primary forest. The peak of the flooding events occurs from November to February. Fluctuations in yearly rainfall influence the range and duration of these events (from a few days to a month). Therefore, these forests cannot be considered floodplain forests, and they do not have consistent yearly flooding.

Carapa guianensis density was estimated at 25.7 trees per hectare (Klimas et al., 2007). Four 400x400 m plots (16-ha) were established within the reserve, as described by Klimas et al. (2007); two of them comprised the studied seed trees. In 2009, seeds were randomly collected from 15 seed trees present in 
the occasionally inundated forest: six in plot 1 and nine in plot 3 . In plot 1 , the average distance between trees was $164.6 \mathrm{~m}$, with minimum distance of $111.7 \mathrm{~m}$ and maximum of $229.4 \mathrm{~m}$. In plot 3, the average distance was 93.7, with minimum of $21.9 \mathrm{~m}$ and maximum of $227.7 \mathrm{~m}$. Approximately 20 open-pollinated seeds were germinated from each seed tree (progenies). Twelve plants per progeny were evaluated by SSRs, totaling 180 individuals.

Genomic DNA samples were isolated from fresh leaves using cetyltrimethylammonium bromide (CTAB), according to Martins et al. (2012). Seven microsatellite loci described by Vinson et al. (2005) (Cg01, Cg06, $\mathrm{Cg} 12, \mathrm{Cg} 16$, and $\mathrm{Cg} 17)$, and by Dayanandan et al. (1999) (Cg05 and Cg07) were tested, but only four ( $\mathrm{Cg} 05, \mathrm{Cg} 06, \mathrm{Cg} 07$, and $\mathrm{Cg} 16)$ were used for the genetic analysis. The polymerase chain reaction (PCR) contained: $50 \mathrm{mmol} \mathrm{mL}^{-1} \mathrm{KCl}, 20 \mathrm{mmol} \mathrm{mL}^{-1}$ Tris-HCl (pH 8.8), $2 \mathrm{mmol} \mathrm{mL}^{-1} \mathrm{MgCl}_{2}, 2.5 \mathrm{U}$ Taq polymerase, $0.25 \mathrm{mmol} \mathrm{mL}^{-1} \mathrm{dNTP}, 0.8 \mu \mathrm{mol} \mathrm{mL} \mathrm{m}^{-1}$ of each primer (forward and reverse), $0.25 \mathrm{mg} \mathrm{mL}^{-1}$ BSA, and $7.5 \mathrm{ng}$ of DNA. All PCR amplifications were performed using a touchdown cycling consisting of the following: $95^{\circ} \mathrm{C}$ for $5 \mathrm{~min}$, four cycles of $95^{\circ} \mathrm{C}$ for $1 \mathrm{~min}, 55^{\circ} \mathrm{C}$ for $1 \mathrm{~min}$, and $72^{\circ} \mathrm{C}$ for $1 \mathrm{~min}$, followed by 20 cycles of $95^{\circ} \mathrm{C}$ for $30 \mathrm{~s}, 65^{\circ} \mathrm{C}$ for $1 \mathrm{~min}$ (with annealing temperature dropping $1^{\circ} \mathrm{C}$ per cycle), $72^{\circ} \mathrm{C}$ for $1 \mathrm{~min}$, followed by a final extension of $72^{\circ} \mathrm{C}$ for $5 \mathrm{~min}$. The amplification products were separated in $6 \%$ denaturing polyacrylamide gels and visualized after silver staining. Allele size scoring was performed using a 10 bp DNA ladder (Life Technologies do Brasil Ltda., São Paulo, SP, Brazil).

The software Genetic Data Analysis (GDA) (Lewis \& Zaykin, 2002) was used to estimate the average number of alleles per locus, observed $\left(\mathrm{H}_{\mathrm{o}}\right)$ and expected heterozygosities $\left(\mathrm{H}_{\mathrm{e}}\right)$, and the fixation index $(\mathrm{F})$ in the progeny array. To test if the average $\mathrm{F}$ was significantly different from zero, 1,000 bootstrap replicates were used, with the GDA program.

The mating system at the levels of population and individual was analyzed according to the mixed mating (Ritland \& Jain, 1981) and correlated mating (Ritland, 1989) models, using the mLTR software, version 3.1 (Ritland, 2002). The mixed mating model assumes that: each mating represents a random event of an outcross or a self-fertilization, with probabilities equal to $t$ and $s(1-t)$, respectively; no mutation and selection following fertilization may occur between fertilization and DNA analysis; and that there is no assortative mating (the probability of an outcross is independent of the maternal or paternal genotypes) (Ritland \& Jain, 1981). The following parameters were estimated within progeny arrays: maximum-likelihood (ME) of single-locus $\left(\mathrm{t}_{\mathrm{s}}\right)$ and multilocus $\left(\mathrm{t}_{\mathrm{m}}\right)$ outcrossing rates, biparental inbreeding $\left(t_{m}-t_{s}\right)$, and correlation of paternity $\left(\mathrm{r}_{\mathrm{p}(\mathrm{m})}\right)$ and of selfing $\left(\mathrm{r}_{\mathrm{s}}\right)$. The average frequency of pairwise of self-sibs $\left(\mathrm{P}_{\mathrm{ss}}\right)$, half-sibs $\left(\mathrm{P}_{\mathrm{hs}}\right)$, full-sibs $\left(\mathrm{P}_{\mathrm{fs}}\right)$, and self-half-sibs $\left(\mathrm{P}_{\mathrm{shs}}\right)$ within progenies was respectively estimated as (Sebbenn, 2006): $\mathrm{P}_{\mathrm{ss}}=\mathrm{s}^{2} ; \mathrm{P}_{\mathrm{hs}}=\mathrm{t}_{\mathrm{m}}{ }^{2}\left(1-\mathrm{r}_{\mathrm{p}(\mathrm{m})}\right) ; \mathrm{P}_{\mathrm{fs}}=\mathrm{t}_{\mathrm{m}}{ }^{2} \mathrm{x} \mathrm{r}_{\mathrm{p}(\mathrm{m})}$; and $\mathrm{P}_{\mathrm{shs}}=2 \mathrm{st}_{\mathrm{m}}$. The effective number of pollen donors was estimated by $\mathrm{N}_{\mathrm{ep}}=1 / \mathrm{r}_{\mathrm{p}(\mathrm{m})}$ (Ritland, 1989). The $95 \%$ confidence interval of the parameters was calculated based on 1,000 bootstraps between individuals within progeny array. The average coancestry coefficient within progenies was estimated from the mating system parameter by $\Theta=0.125\left(1+\mathrm{F}_{\mathrm{p}}\right)\left|4 \mathrm{~s}+\left(\mathrm{t}_{\mathrm{m}}{ }^{2}+\mathrm{t}_{\mathrm{m}} \times \mathrm{sr}_{\mathrm{s}}\right)\left(1+\mathrm{r}_{\mathrm{p}(\mathrm{m})}\right)\right|$, in which $F_{p}$ is the inbreeding in the parental population. This estimator corresponds to half of the relatedness coefficient within families $(\Theta=r / 2)$, as derived by Ritland (1989). The variance effective size $\left(\mathrm{N}_{\mathrm{e}(\mathrm{v})}\right)$ was estimated by $\mathrm{N}_{\mathrm{e}(\mathrm{v})}=0.5 /\left\{\Theta[(\mathrm{n}-1) / \mathrm{n}]+\left(1+\mathrm{F}_{\mathrm{s}}\right) / 2 \mathrm{n}\right\}$ (Cockerham, 1969), in which $F_{s}$ is the inbreeding coefficient of the seeds and $n$ is the sample size $(n=100$ was assumed to exclude the effect of sample size on the estimation of $\mathrm{N}_{\mathrm{e}(\mathrm{v})}$ ). The minimum number of seed trees required for harvesting, for conservation purposes, was calculated by $\mathrm{m}=\mathrm{N}_{\mathrm{e} \text { (reference) }} / \mathrm{N}_{\mathrm{e}(\mathrm{v})}$ (Sebbenn, 2006), in which $\mathrm{N}_{\mathrm{e}(\text { reference) }}$ is the required effective population size for conservation purposes, which, according to Lacerda et al. (2008), means 150 individuals.

\section{Results and Discussion}

Of the seven microsatellite tested, four were polymorphic: $\mathrm{Cg} 05, \mathrm{Cg} 06, \mathrm{Cg} 07$, and $\mathrm{Cg} 16$. They were used to genotype the seeds. The remaining three loci were monomorphic ( $\mathrm{Cg} 12)$ or had stutter bands (Cg17 and $\mathrm{Cg} 01$ ). In this last case, the genotyping profile was not clear and, therefore, these loci were not included. The number of alleles per locus ranged from four to eight, with an average of 5.75 alleles per locus. The expected heterozygosity varied from 0.628 to 0.770 (average of 0.724 ), and the observed heterozygosity ranged from 0.326 to 0.756 (average 
of 0.570 ). The expected heterozygosity was similar to the one estimated by Cloutier et al. (2007b), using six microsatellite loci in a $C$. guianensis population from the Brazilian Amazon forest, with seeds collected before and after logging ( 0.69 and 0.70 , respectively). However, Cloutier et al. (2007b) estimated higher values of observed heterozygosity, before and after logging ( 0.68 and 0.67 , respectively).

The multilocus outcrossing rate $\left(\mathrm{t}_{\mathrm{m}}=0.862\right)$ was significantly lower than the unity (1.0), indicating that some selfing occurred (Table 1). Even with the few microsatellite markers used, the estimated multilocus outcrossing rate, in general, was not significantly different from those reported in other populations, in previous studies with allozymes $\left[\mathrm{t}_{\mathrm{m}}=0.967\right.$ before and $\mathrm{t}_{\mathrm{m}}=0.986$ after logging (Hall et al., 1994)] and with microsatellite loci $\left[\mathrm{t}_{\mathrm{m}}=0.939\right.$ before and $\mathrm{t}_{\mathrm{m}}=0.927$ after logging (Cloutier et al., 2007b); and $\mathrm{t}_{\mathrm{m}}=0.918$ (Cloutier et al., 2007a)]. This significantly lower rate reflects the stability of crossing rates in C. guianensis, even in different populations, years, environmental conditions, and samples. Therefore, the present study and the ones reported above show that outcrossing is predominant in the species, which is favorable to maintain the genetic diversity and the effective population size of populations. However, the correlation of selfing was high $\left(r_{s}=0.635\right)$, indicating high variation in individual outcrossing rates (Table 2 ), ranging among progenies from 0.598 to 0.978 . This result contrasts to some extent with the ones reported by Maués (2006), who observed the presence of a partial pre-zygotic incompatibility system in the species. According to the results obtained in the present study, the species is not self-incompatible.

Table 1. Mating system parameters of Carapa guianensis.

\begin{tabular}{lc}
\hline Parameter & Mean $(95 \%$ confidence interval $)$ \\
\hline Multilocus outcrossing rate $\left(\mathrm{t}_{\mathrm{m}}\right)$ & $0.862(0.764$ to 0.948$)$ \\
Single-locus outcrossing rate $\left(\mathrm{t}_{\mathrm{s}}\right)$ & $0.728(0.652$ to 0.826$)$ \\
Biparental inbreeding $\left(\mathrm{t}_{\mathrm{m}}-\mathrm{t}_{\mathrm{s}}\right)$ & $0.134(0.112$ to 0.122$)$ \\
Correlation of selfing $\left(\mathrm{r}_{\mathrm{s}}\right)$ & $0.635(0.449$ to 0.954$)$ \\
Multilocus correlation of paternity $\left(\mathrm{r}_{\mathrm{p}(\mathrm{m})}\right)$ & $0.081(0.002$ to 0.138$)$ \\
Pairwise frequency of self-sibs $\left(\mathrm{P}_{\mathrm{ss}}\right)$ & $0.019(0.003$ to 0.056$)$ \\
Pairwise frequency of half-sibs $\left(\mathrm{P}_{\mathrm{hs}}\right)$ & $0.683(0.503$ to 0.897$)$ \\
Pairwise frequency of full-sibs $\left(\mathrm{P}_{\mathrm{fs}}\right)$ & $0.060(0.002$ to 0.081$)$ \\
Pairwise frequency of self-half-sibs $\left(\mathrm{P}_{\mathrm{shs}}\right)$ & $0.238(0.099$ to 0.361$)$ \\
Effective number of pollen donors $\left(\mathrm{N}_{\mathrm{ep}}\right)$ & $12.3(7.7$ to 500$)$ \\
Coancestry within progenies $(\Theta)$ & $0.185(0.141$ to 0.264$)$ \\
Variance effective size $\left(\mathrm{N}_{\mathrm{e}(\mathrm{v})}\right)$ & $2.7(1.9$ to 3.5$)$ \\
Number of seed trees to collect seeds $(\mathrm{m})$ & $56(43$ to 80$)$ \\
\hline
\end{tabular}

The average single-locus outcrossing rate $\left(t_{s}=0.726\right)$ was also significantly lower than the unity (1.0), and the average difference $\left(\mathrm{t}_{\mathrm{m}}-\mathrm{t}_{\mathrm{s}}=0.134\right)$ was significantly different from zero (Table 1 ). This result was also observed in the progeny level (Table 2), indicating that biparental inbreeding may have occurred. Biparental inbreeding can be explained by the presence of some related individuals within the population. Martins et al. (2012), studying the same population, did not find significant SGS. However, it is important to note that the absence of significant SGS does not mean the absence of relatives within the population, only that they are not spatially structured. The estimates of biparental inbreeding were also higher than those detected by Cloutier et al. (2007b) before $\left(t_{m}-t_{s}=0.015\right)$ and after logging $\left(t_{m}-t_{s}=0.028\right)$. One possible explanation for this may be the presence of different levels of genetic load, in which the present population may have lower levels than the population studied by Cloutier et al. (2007b). In this case, it would have resulted in low inbreeding depression in the studied population. A study with inbreeding depression estimated in seeds collected from both populations could precisely explain these contrasting results.

The average multilocus correlation of paternity was low $\left(\mathrm{r}_{\mathrm{p}(\mathrm{m})}=0.081\right)$, but significantly different from zero (Table 1). At individual level, this parameter ranged from 0.049 to 0.240 (Table 2), and generally it was

Table 2. Mating system parameters $( \pm \mathrm{SD})$ at the individual level in Carapa guianensis ${ }^{(1)}$.

\begin{tabular}{lcrcrcc}
\hline Progeny & $\mathrm{t}_{\mathrm{m}}$ & \multicolumn{1}{c}{$\mathrm{t}_{\mathrm{m}}-\mathrm{t}_{\mathrm{s}}$} & $\mathrm{r}_{\mathrm{p}(\mathrm{m})}$ & \multicolumn{1}{c}{$\mathrm{N}_{\mathrm{ep}}$} & $\Theta$ & $\mathrm{N}_{\mathrm{e}(\mathrm{v})}$ \\
\hline 1 & $0.732 \pm 0.170$ & $-0.096 \pm 0.119$ & $0.115 \pm 0.067$ & 14.9 & 0.209 & 2.36 \\
2 & $0.938 \pm 0.071$ & $0.073 \pm 0.062$ & $0.072 \pm 0.022$ & 45.5 & 0.149 & 3.28 \\
3 & $0.949 \pm 0.059$ & $0.045 \pm 0.040$ & $0.094 \pm 0.045$ & 22.2 & 0.149 & 3.29 \\
4 & $0.944 \pm 0.074$ & $0.201 \pm 0.055$ & $0.240 \pm 0.137$ & 7.3 & 0.166 & 2.95 \\
5 & $0.951 \pm 0.081$ & $0.103 \pm 0.060$ & $0.117 \pm 0.086$ & 11.6 & 0.151 & 3.24 \\
6 & $0.969 \pm 0.040$ & $0.109 \pm 0.051$ & $0.107 \pm 0.076$ & 13.2 & 0.145 & 3.36 \\
7 & $0.598 \pm 0.176$ & $-0.115 \pm 0.098$ & $0.154 \pm 0.081$ & 12.3 & 0.253 & 1.96 \\
8 & $0.978 \pm 0.011$ & $0.034 \pm 0.007$ & $0.133 \pm 0.074$ & 13.5 & 0.146 & 3.33 \\
9 & $0.971 \pm 0.012$ & $0.073 \pm 0.020$ & $0.062 \pm 0.019$ & 52.6 & 0.140 & 3.49 \\
10 & $0.954 \pm 0.074$ & $0.085 \pm 0.056$ & $0.122 \pm 0.120$ & 8.3 & 0.151 & 3.24 \\
11 & $0.833 \pm 0.145$ & $-0.051 \pm 0.101$ & $0.055 \pm 0.011$ & 90.9 & 0.175 & 2.80 \\
12 & $0.702 \pm 0.174$ & $-0.139 \pm 0.111$ & $0.049 \pm 0.015$ & 66.7 & 0.214 & 2.31 \\
13 & $0.841 \pm 0.137$ & $-0.027 \pm 0.081$ & $0.057 \pm 0.019$ & 52.6 & 0.173 & 2.84 \\
14 & $0.747 \pm 0.155$ & $-0.096 \pm 0.093$ & $0.053 \pm 0.011$ & 90.9 & 0.200 & 2.46 \\
15 & $0.871 \pm 0.123$ & $0.040 \pm 0.074$ & $0.052 \pm 0.018$ & 55.6 & 0.164 & 2.98 \\
\hline
\end{tabular}

${ }^{(1)} t_{m}$, multilocus outcrossing rate; $t_{m}-t_{s}$, biparental inbreeding; $r_{p(m)}$, multilocus correlation of paternity; $\mathrm{N}_{\mathrm{ep}}$, effective number of pollen donors; $\Theta$, coancestry within families; $\mathrm{N}_{\mathrm{e}(\mathrm{v})}$, variance effective size. SD, the standard deviation based on 1,000 bootstrap replicates. 
significantly different from zero. The estimates of $r_{p(m)}$ suggest that the progenies contain some full-sib individuals (an average of 7\%), mix with self-sibs, half-sibs, and self-half-sibs (Table 1). Consequently, the number of pollen donors was substantial in the average population level $\left(\mathrm{N}_{\mathrm{ep}}=12.3\right.$, Table 1) and in the progeny level $\left(\mathrm{N}_{\mathrm{ep}}\right.$ ranging from 7.3 to 90.9 , Table 2). These values suggest random mating, which is reasonable, considering the high density of C. guianensis adult trees in the area (Klimas et al., 2007), which would enable intense gene flow by pollen dispersal.

The average fixation index (0.213) was significantly different from zero, indicating inbreeding in the progeny array. Although Cloutier et al. (2007a) also found significant positive values of fixation index, before and after logging ( 0.025 and 0.049 , respectively), the estimated value in the present study indicates higher inbreeding levels, which could be explained by a lower outcrossing rate and higher biparental inbreeding $\left(\mathrm{t}_{\mathrm{m}}-\mathrm{t}_{\mathrm{s}}=0.134\right)$.

The coancestry coefficient within progenies $(\Theta=0.185)$ was higher and the variance effective size $\left(\mathrm{N}_{\mathrm{e}(\mathrm{v})}=2.7\right)$ was lower than expected for true half-sib progenies $\left(\Theta=0.125 ; \mathrm{N}_{\mathrm{e}(\mathrm{v})}=4\right)$, in both population levels (Table 1) and progenies (Table 2). The main cause was the substantial selfing observed and the individual variation in the outcrossing rate, as well the correlation of paternity. Selfing and correlation of paternity increase the relatedness and, consequently, the frequency of identity by decent alleles within progenies (Sebbenn, 2006).

The results suggested that it is necessary to collect seeds from at least 56 seed trees in order to obtain progeny arrays with an effective size of 150 . The definition of the necessary number of seed trees to develop breeding, ex situ genetic conservation, and environmental reforestation programs provide the minimum effective population size for these purposes (Sebbenn, 2003, 2006, 2011). This number will ensure the evolutionary potential of the artificially funded populations.

\section{Conclusions}

1. Although Carapa guianensis is predominantly outcrossed, average selfing rates are substantial and larger than the ones found in populations from Eastern Amazonia.
2. In order to retain the effective size of 150 for breeding, ex situ genetic conservation, and environmental reforestation programs, it is necessary to collect seeds from at least 56 seed trees.

\section{Acknowledgments}

To Conselho Nacional de Desenvolvimento Científico e Tecnológico (CNPq), for financial support.

\section{References}

CLOUTIER, D.; HARDY, O.J.; CARON, H.; CIAMPI, A.Y.; DEGEN, B.; KANASHIRO, M.; SCHOEN, D.J. Low inbreeding and high pollen dispersal distances in populations of two Amazonian forest tree species. Biotropica, v.39, p.406-415, 2007a. DOI: $10.1111 /$ j.1744-7429.2007.00266.x.

CLOUTIER, D.; KANASHIRO, M.; CIAMPI, A.Y.; SCHOEN, D.J. Impact of selective logging on inbreeding and gene dispersal in an Amazonian tree population of Carapa guianensis Aubl. Molecular Ecology, v.16, p.797-809, 2007b. DOI: 10.1111/j.136 5-294X.2006.03193.x.

COCKERHAM, C.C. Variance of gene frequencies. Evolution, v.23, p.72-84, 1969. DOI: 10.2307/2406485.

DAYANANDAN, S.; DOLE, J.; BAWA, K.; KESSELI, R. Population structure delineated with microsatellite markers in fragmented populations of a tropical tree, Carapa guianensis (Meliaceae). Molecular Ecology, v.8, p.1585-1592, 1999. DOI: 10.1046/j.1365-294x.1999.00735.x.

FERES, J.M.; SEBBENN, A.M.; GUIDUGLI, M.C.; MESTRINER, M.A.; MORAES, M.L.T.; ALZATE-MARIN, A.L. Mating system parameters at hierarchical levels of fruits, individuals and populations in the Brazilian insect-pollinated tropical tree, Tabebuia roseo-alba (Bignoniaceae). Conservation Genetics, v.13, p.393-405, 2012. DOI: 10.1007/s10592-011-0292-z.

HALL, P.; ORREL, L.; BAWA, K.S. Genetic diversity and mating system in a tropical tree, Carapa guianensis (Meliaceae). American Journal of Botany, v.81, p.1104-1111, 1994. DOI: $10.2307 / 2445472$

KLIMAS, C.A.; KAINER, K.A.; WADT, L.H.O. Population structure of Carapa guianensis in two forest types in the southwestern Brazilian Amazon. Forest Ecology and Management, v.250, p.256-265, 2007. DOI: 10.1016/j.foreco.2007.05.025.

LACERDA, A.E.B. de; KANASHIRO, M.; SEBBENN, A.M. Long-pollen movement and deviation of random mating in a low-density continuous population of Hymenaea courbaril in the Brazilian Amazon. Biotropica, v.40, p.462-470, 2008. DOI: 10.1111/j.1744-7429.2008.00402.x.

LEWIS, P.O.; ZAYKIN, D. Genetic data analysis (GDA): computer program for the analysis of allelic data (software). Version 1.1. Albuquerque: University of New Mexico, 2002. Available at: <http://www.eeb.uconn.edu/people/plewis/software. php>. Accessed on: 20 Aug. 2012. 
MARTINS, K.; RAPOSO, A.; KLIMAS, C.A.; VEASEY, E.A.; KAINER, K.; WADT, L.H.O. Pollen and seed flow patterns of Carapa guianensis Aublet. (Meliaceae) in two types of Amazonian forest. Genetics and Molecular Biology, v.35, p.818-826, 2012. DOI: 10.1590/S1415-47572012005000068.

MAUÉS, M.M. Estratégias reprodutivas de espécies arbóreas e a sua importância para o manejo e conservação florestal: Floresta Nacional de Tapajós (Belterra-PA). 2006. 209p. Tese (Doutorado) - Universidade de Brasília, Brasília.

RAPOSO, A.; MARTINS, K.; CIAMPI, A.Y.; WADT, L.H. de O.; VEASEY, E.A. Diversidade genética de populações de andiroba no Baixo Acre. Pesquisa Agropecuária Brasileira, v.42, p.1291-1298, 2007. DOI: 10.1590/S0100-204X2007000900011.

REVILLA, J. Plantas da Amazônia: oportunidades econômicas e sustentáveis. Manaus: SEBRAE: INPA, 2001. 405p.

RITLAND, K. Correlated matings in the partial selfer Mimulus guttatus. Evolution, v.43, p.848-859, 1989. DOI: 10.2307/2409312.

RITLAND, K. Extensions of models for the estimation of mating systems using $\mathrm{n}$ independent loci. Heredity, v.88, p.221-228, 2002. DOI: 10.1038/sj.hdy.6800029.
RITLAND, K.; JAIN, S. A model for the estimation of outcrossing rate and gene frequencies using independent loci. Heredity, v.47, p.35-52, 1981. DOI: 10.1038/hdy.1981.57.

SEBBENN, A.M. Effects of forest fragmentation on the effective and realized gene flow of Neotropical tree species: implications for genetic conservation. BMC Proceedings, v.5, 2011. DOI: 10.1186/1753-6561-5-S7-O6.

SEBBENN, A.M. Sistema de reprodução em espécies arbóreas tropicais e suas implicações para a seleção de árvores matrizes para reflorestamentos ambientais. In: HIGA, A.R.; SILVA, L. (Coord.). Pomares de sementes de espécies florestais nativas. Curitiba: FUPEF, 2006. p.193-198.

SEBBENN, A.M. Tamanho amostral para conservação ex situ de espécies arbóreas com sistema misto de reprodução. Revista do Instituto Florestal, v.15, p.147-162, 2003.

VINSON, C.C.; AZEVEDO, V.C.R.; SAMPAIO, I.; CIAMPI, A.Y. Development of microsatellite markers for Carapa guianensis (Aublet), a tree species from the Amazon Forest. Molecular Ecology Notes, v.5, p.33-34, 2005. DOI: 10.1111/j.1471-8286.20 04.00821.x.

Received on October 2, 2012 and accepted on April 17, 2013 